\title{
FIDUCIARY LAW AND THE CONSTRUCTIVE TRUST: PERFECTING THE FIDUCIARY UNDERTAKING
}

\author{
CIARA J TOOLE
}

Two recent unanimous decisions from the Supreme Court of Canada in Galambos v Perez and Alberta v Elder Advocates of Alberta Society have narrowed and refreshed the requirements for recognizing fiduciary relationships and obligations. All fiduciary obligations must be founded by an undertaking, either express or implied, on the part of the fiduciary to act in the best interest of the beneficiary. At the heart of the fiduciary obligation, the undertaking of a fiduciary may also serve as a foundation for the goals of fiduciary accountability. The developing "Galambos approach" remains incomplete in its application in this regard. In the spirit of Galambos and Elder Advocates, I propose that the undertaking of the fiduciary can provide principled guidance in the availability of gain-based relief for breach of fiduciary duty. Particularly, I suggest that the imposition of a constructive trust as proprietary gain-based relief may be rationalized under the objective of perfecting or enforcing the fiduciary undertaking. To demonstrate my proposal, I investigate three example undertakings and breaches of fiduciary duty in which the fiduciary acquires property through the breach of duty. By grounding this overall discussion towards a conceptual remedial goal of enforcing the fiduciary's undertaking, Galambos may spark the development of a principled approach to understanding both the making and the breach of fiduciary obligations.
Deux récentes décisions unanimes de la Cour suprême du Canada, notamment Galambos c Perez et Alberta c Elder Advocates of Alberta Society restreignent et actualisent les exigences relatives à la reconnaissance des relations et des obligations fiduciaires. Les obligations fiduciaires doivent reposer sur un engagement, exprès ou tacite, de la part du fiduciaire d'agir dans le meilleur intérêt du bénéficiaire. Au cœur de cette obligation, l'engagement du fiduciaire peut aussi servir de base des objectifs de la responsabilité. L'«approche Galambos» demeure cependant incomplète dans sa demande à cet égard. Dans l'esprit de Galambos et de Elder Advocates, je propose que l'engagement du fiduciaire assure une direction fondée sur des principes dans la disponibilité d'aide basée sur le gain de poids pour violation de responsabilité fiduciaire. Je suggère tout particulièrement l'imposition d'une fiducie constructoire étant donné que l'aide basée sur le gain de poids exclusif peut être motivée par l'objectif de parfaire ou d'exécuter l'engagement fiduciaire. Dans le but de démontrer ma proposition, j'examine trois exemples d'engagement et de violation de responsabilité fiduciaire où le fiduciaire acquière des biens par la violation de cette responsabilité. En fondant cette discussion générale sur le recours conceptuel d'exécuter l'engagement fiduciaire, Galambos pourrait déclencher le développement d'une approche fondée sur des principes pour comprendre à la fois la conclusion et la violation des obligations fiduciaires.

\section{TABLE OF CONTENTS}

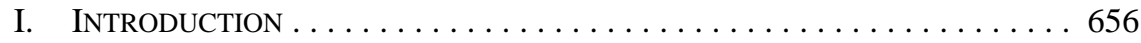

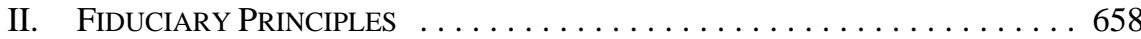
A. FIDUCIARY RELATIONSHIPS -
THE IMPORTANCE OF THE UNDERTAKING . . . . . . . . . . . . . 658

B. Fiduciary AcCountabiLity AND THE UndERTAKING $\ldots \ldots \ldots 662$

III. PROPRIETARY REMEDY FOR BREACH OF FIDUCIARY DUTY

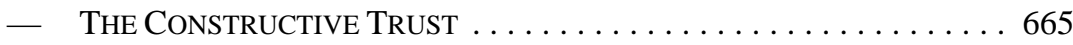

IV. Perfecting the Fiduciary Undertaking . . . . . . . . . . . . 669

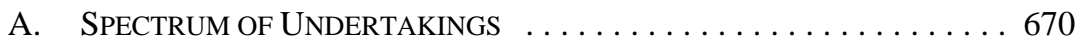

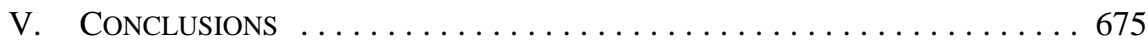

* LLB, Student-at-Law. This article was awarded first place, General Category, in the Alberta Law Review's 2011/12 William Morrow Essay contest. 


\section{INTRODUCTION}

With the welcomed release of two unanimous decisions from the Supreme Court of Canada in Galambos $v$ Perez $^{1}$ and Alberta $v$ Elder Advocates of Alberta Society, ${ }^{2}$ the requirements for recognizing fiduciary relationships and obligations have been narrowed and refreshed. Reducing confusion and finally uniting the Court in the area of fiduciary law, Justice Cromwell held in Galambos that all fiduciary obligations must be founded by an undertaking, either express or implied, on the part of the fiduciary to act in the interest of the other party. ${ }^{3}$ Where this undertaking provides the fiduciary with a "discretionary power to affect the other party's legal or [substantial] practical interests," ${ }^{4}$ the law provides a strict legal framework of liability in accordance with the scope of fiduciary obligations. ${ }^{5}$ This undivided direction from the Supreme Court was echoed by Chief Justice McLachlin in Elder Advocates, providing a powerful tool through which to recognize fiduciary relationships ${ }^{6}$ and understand the scope of fiduciary duty and liability from the nature of the fiduciary relationship itself. ${ }^{7}$ Nevertheless, the "Galambos approach" remains new and incomplete in its application in determining the scope of fiduciary duties and accountability. ${ }^{8}$

Through a traditionally broad remedial reach, fiduciary law recognizes the right of a beneficiary to gain-based relief, depriving the fiduciary from profits or benefits earned as a result of a breach of duty. ${ }^{9}$ Pursuant to the overarching goal of protecting fiduciary relationships of trust and confidence in society, ${ }^{10}$ gain-based relief has often been rationalized as representing either restitution of a fiduciary's unjust enrichment ${ }^{11}$ or disgorgement of a fiduciary's ill-gotten gain for general deterrence of future wrongdoing. ${ }^{12}$ However, the application of these individual remedial concerns has been subject to considerable debate and

2009 SCC 48, [2009] 3 SCR 247 [Galambos]. See Cristin Schmitz, "SCC to Rule on Law of Lawyers' Roles: Spring Docket has Cases Exploring Lawyers’ Duties as Fiduciaries and to Court” (2009) 28:46 The Lawyers Weekly; Cristin Schmitz, "Supreme Court of Canada Clarifies Law of Fiduciary Duty: No Special Rules For 'Power Dependency' Relationships” (2009) 29:25 The Lawyers Weekly. 2011 SCC 24, [2011] 2 SCR 261 [Elder Advocates]. See Cristin Schmitz, "SCC Rejects Novel Fiduciary Duty Claim: Claims Against Government will ‘Rarely’ Succeed: Top Court” (2011) 31:4 The Lawyers Weekly.

Galambos, supra note 1 at para 71.

Ibid at para 83; Elder Advocates, supra note 2 at para 36.

Galambos, ibid at para 37; Leonard I Rotman, Fiduciary Law (Toronto: Thomson Carswell, 2005) at 2 [Rotman, Fiduciary Law]; John D McCamus, "Prometheus Unbound: Fiduciary Obligation in the Supreme Court of Canada” (1997) 28 Can Bus LJ 107 at 108-109.

Robert Flannigan, "Fact-Based Fiduciary Accountability in Canada” (2010) 36:4 Advocates' Q 431 [Flannigan, "Fiduciary Accountability"] (called a "fresh start" for the recognition of fiduciary obligations at 455).

Paul B Miller, “A Theory of Fiduciary Liability” (2011) 56:2 McGill LJ 235 at 281; Galambos, supra note 1 (importance of the relationship emphasized at para 70).

$8 \quad$ Miller, ibid at 287-88.

9 Anthony Duggan, "Gains-Based Remedies and the Place of Deterrence in the Law of Fiduciary Obligations" in Andrew Robertson \& Tang Hang Wu, eds, The Goals of Private Law (Oxford: Hart Publishing, 2009) 365 at 365 [Duggan, "Gains-Based Remedies"].

10 Soulos v Korkontzilas, [1997] 2 SCR 217 at para 33 [Soulos]; JR Maurice Gautreau, "Unjust Enrichment, Fiduciary Loyalty, and Remedies” (1986) 5:2 Advocates' Soc J 4 at 8.

11 See Lac Minerals Ltd v International Corona Resources Ltd, [1989] 2 SCR 574 [Lac Minerals] (dissent on presence of a fiduciary relationship by Justice Sopinka).

12 See Keech $v$ Sandford (1726), 25 ER 223 (Ch D) [Keech]; Soulos, supra note 10 at para 33, citing Hodgkinson v Simms, [1994] 3 SCR 377 at 453 [Hodgkinson]; Strother $v 3464920$ Canada Inc, 2007 SCC 24, [2007] 2 SCR 177 [Strother]. See also Anthony Duggan, "Constructive Trusts from a Law and Economics Perspective" (2005) 55 UTLJ 217 at 217 [Duggan, "Constructive Trusts"]. 
has resulted in a distorting of the traditional availability of a constructive trust as proprietary gain-based relief for breach of fiduciary duty. ${ }^{13}$

At the heart of the fiduciary obligation, the undertaking may also serve as a foundation for the goals of fiduciary accountability. In the spirit of Galambos and Elder Advocates, I propose that the undertaking of the fiduciary can provide principled guidance in the availability of a gain-based remedy for breach of fiduciary duty. Particularly, I suggest that the imposition of a constructive trust as proprietary gain-based relief may be rationalized under the objective of perfecting or enforcing the fiduciary undertaking. In Part II of this article, I explore the Galambos theory and the importance of the undertaking at the heart of the fiduciary relationship. Looking then to fiduciary accountability and gain-based relief for breach of fiduciary duty, I broadly identify the tension in awarding gain-based relief to meet restitutionary and deterrence goals. In Part III, this tension is particularly illustrated in the unprincipled application of the constructive trust as proprietary gain-based relief for breach of fiduciary duty. Finally in Part IV, I argue that by extending the Galambos approach and heeding the traditional maxim, equity deems to be done what ought to be done,${ }^{14}$ the constructive trust may be principally available as proprietary gain-based relief where it is possible to enforce the fiduciary's undertaking through a proprietary remedy. To demonstrate this proposal, I investigate three example undertakings and breaches of fiduciary duty in which the fiduciary acquires property through the breach of duty. ${ }^{15}$ Examining the connections between the source of fiduciary obligations, the remedial goals of fiduciary law, and the nature of the constructive trust, this approach views the undertaking as a starting place for our understanding of the fiduciary relationship as well as a key basis for the principled availability of proprietary gain-based relief.

The far-reaching effects of proprietary relief necessarily paints the constructive trust as a contentious remedy. ${ }^{16}$ This analysis does not purport to provide comprehensive direction on the criteria or third-party interests to be considered by a court in the specific imposition of a constructive trust as proprietary relief for breach of fiduciary duty. Rather, by expanding the importance of the undertaking to this context of fiduciary accountability, it is hoped that a re-evaluation of the objectives of gain-based proprietary relief will spark further discussion and strengthen the explanatory power of the Galambos approach.

McCamus, supra note 5 at 118; AH Oosterhoff et al, Oosterhoff on Trusts: Text, Commentary and Materials, 7th ed (Toronto: Carswell, 2009) at 827; Duggan, "Gains-Based Remedies," supra note 9 at 365; James Edelman, "Gain-Based Damages and Compensation" in Andrew Burrows \& Alan Rodger, eds, Mapping the Law: Essays in Memory of Peter Birks (Oxford: Oxford University Press, 2006) 141 at 150 [Edelman, "Gain-Based"].

14 A-G for Hong Kong v Reid (1993), [1994] 1 AC 324 at 331 (PC) [Reid] (where Lord Templeman cites the maxim: "Equity considers as done that which ought to have been done"); Banks $v$ Sutton (1732), 24 ER 922 at 928.

15 The examples discussed lie on a spectrum of certainty in the possible availability of proprietary gainbased relief under the existing Canadian law of constructive trusts and are similar to examples based on the property theory of availability of a constructive trust. See Roy Goode, "Property and Unjust Enrichment" in Andrew Burrows, ed, Essays on the Law of Restitution (Oxford: Clarendon Press, 1991); Peter Birks, An Introduction to the Law of Restitution (Oxford: Clarendon Press, 1989) at 377-92.

16 Including, in particular, providing the beneficiary with priority over creditors in the case of insolvency of the fiduciary if the constructive trust is recognized as of the date of the breach. See Mitchell McInnes, "Unjust Enrichment and Constructive Trusts in the Supreme Court of Canada" (1997-1998) 25:3 Man LJ 513 at 514-15; Goode, ibid; Thomas Allen, "Bribes and Constructive Trusts: A-G of Hong Kong v Reid” (1995) 58:1 Mod L Rev 87 at 92. 


\section{FiduCIARY PRINCIPLES}

\section{A. FIDUCIARY RELATIONSHIPS - THE IMPORTANCE OF THE UNDERTAKING}

Until this point in Canadian fiduciary law, the importance of the fiduciary concept has been plagued by its resistance to definition and also confusion in its application to traditional and new relational circumstances. ${ }^{17}$ While individuals are presumptively self-reliant and unaccountable to others, ${ }^{18}$ equity recognizes some circumstances where a person should be held to a higher ethic in his or her relation to another. ${ }^{19}$ Historically, these "fiduciary" relationships were drawn by analogy from the archetypal express trust relationship, where one person holds property for the sole benefit of another. ${ }^{20}$ By identifying analogous categories of relationships of inherent trust and confidence, fiduciary law has required persons in a wide range of circumstances to ascribe to high standards of conduct in regards to their duties owed to the beneficiaries of the relationship. ${ }^{21}$ On this basis, status-based per se fiduciary relationships have been identified to include the agent-principal, solicitorclient, ${ }^{22}$ and doctor-patient relationships. ${ }^{23}$ Nevertheless, considering the broader goal of fiduciary law to protect the integrity of relationships of special trust and confidence in society, ${ }^{24}$ the Supreme Court of Canada has held that the categories of fiduciary obligations are not closed. ${ }^{25}$ From this assertion, fiduciary law has searched for a principled, fact-based approach to the identification of fiduciary relationships. ${ }^{26}$

Historically, in Canadian jurisprudence, fiduciary obligations have been recognized through three main approaches. ${ }^{27}$ Firstly, even where a relationship was not of a category traditionally labelled as fiduciary, ad hoc fiduciary obligations could arise as a matter of fact on the basis of the particular relationship between the parties. Similarly, a presumptive fiduciary relationship could be excluded where a fact-based analysis proved it should not be burdened with these obligations. Second, in this regard, a fiduciary relationship could be recognized where the factual relationship between the parties met general indicia of special trust and confidence as laid out by Justice Wilson in Frame $v$ Smith. ${ }^{28}$ These hallmarks included: (1) where "[t]he fiduciary has scope for the exercise of some discretion or power"; (2) where " $t]$ he fiduciary can unilaterally exercise that power or discretion so as to affect the beneficiary’s legal or practical interests”; and (3) where “[t]he beneficiary is peculiarly

Rotman, Fiduciary Law, supra note 5 at 2.

Allen v Flood (1897), [1898] AC 1 (HL (Eng)).

Oosterhoff, supra note 13 at 828.

Douglas A Alderson, "LAC Minerals and the Fiduciary Obligation: The Limits of Commercial Morality" (1991) 10:3 E \& TJ 231 at 252; Miller, supra note 7 at 241; Leonard I Rotman, "Fiduciary Doctrine: A Concept in Need of Understanding” (1996) 34:4 Alta L Rev 821 at 838 [Rotman, "Fiduciary Doctrine”]. Rotman, "Fiduciary Doctrine," ibid at 826.

Read v Cole, [1915] 52 SCR 176.

Norberg v Wynrib, [1992] 2 SCR 226 [Norberg]. See generally Oosterhoff, supra note 13 at 830-31.

Rotman, Fiduciary Law, supra note 5 at 692-93.

Guerin v R, [1984] 2 SCR 335 at 384 [Guerin].

Miller, supra note 7 at 243.

Laid out by Justice La Forest in Lac Minerals, supra note 11 at 643-52.

[1987] 2 SCR 99 at 116, Wilson J, dissenting [Frame]. 
vulnerable to ... the fiduciary."29 Third, the label of a fiduciary relationship has also been imposed simply to achieve particular remedial goals in a case. ${ }^{30}$

These fact-based principles innately resisted characterization as a consistent theory for the identification of a fiduciary relationship. ${ }^{31}$ Between important judgments of the Supreme Court of Canada in Guerin v R, Frame v Smith, Lac Minerals Ltd v International Corona Resources Ltd, Norberg $v$ Wynrib, and Hodgkinson $v$ Simms, ${ }^{32}$ majorities and dissents weighed back and forth on the essential defining characteristics of the fiduciary relationship. ${ }^{33}$ Was a particular special vulnerability invariably required ${ }^{34}$ or was the presence of discretionary power decisive ${ }^{35}$ Some commentators have argued that the nature of fiduciary doctrine is such that it should never be reduced to a simplified theory at the expense of flexibility or scope. ${ }^{36}$ However, while fiduciary law has at times responded as a vehicle of remedy, its flexibility in application should arguably be based on principled and predictable doctrine. $^{37}$

Returning to a conventional and natural understanding of fiduciary doctrine, the Supreme Court of Canada seized the opportunity to recast the recognition of fiduciary relationships in Galambos. ${ }^{38}$ In this case, the Court was faced with the question of fiduciary obligations owed by a law firm in relation to cash advances made by its employee. The law firm, founded by Mr. Galambos, had received some \$200,000 in cash advances from its bookkeeper, Ms. Perez, during a financially difficult period. Galambos did not ask for the advancement of these sums and instructed Perez to reimburse herself from the firm account with interest. Perez did not follow this instruction, but continued to make deposits into the firm account with her personal credit card. The firm's financial condition deteriorated. Perez subsequently claimed compensation for negligence, breach of contract, and breach of fiduciary duty. On the issue of fiduciary duty, Perez argued that she was the beneficiary of a presumptively fiduciary solicitor-client relationship with her employer, based on prior legal work done for her by the firm. In the alternative, she submitted that the cash advances had created a "power-dependency” relationship between herself and Galambos and, as a result, fact-based fiduciary obligations arose in the circumstances.

Rejecting the contention that the loans were made within the scope of a solicitor-client fiduciary relationship, the Court held that “[a] claim for breach of fiduciary duty may only

Ibid at 136

McCamus, supra note 5 (refers to this approach as the "fictitious fiduciary relationship" at 116) [emphasis omitted].

Miller, supra note 7 at 247.

Guerin, supra note 25; Frame, supra note 28; Lac Minerals, supra note 11; Norberg, supra note 23; Hodgkinson, supra note 12.

33 See Oosterhoff, supra note 13 at 830-35; McCamus, supra note 5 (of particular note was the debate between Justice La Forest and Justice Sopinka regarding the requirement of a special vulnerability on the part of the beneficiary at 124-28).

34 Leonard I Rotman, "The Vulnerable Position of Fiduciary Doctrine in the Supreme Court of Canada" (1996) 24:1 Man LJ 60 [Rotman, “The Vulnerable Position”]; Frame, supra note 28; Norberg, supra note 23 at 277-82.

Guerin, supra note 25 at 384.

Rotman, "Fiduciary Doctrine,” supra note 20 at 829; Anthony Duggan, "Fiduciary Obligations in the Supreme Court of Canada: A Retrospective” (2010) [unpublished], online: Social Science Research Network <http://ssrn.com/abstract=1600928> at 2 [Duggan, "Fiduciary Obligations"].

Rotman, Fiduciary Law, supra note 5 at 4-6; Alderson, supra note 20 at 252; McCamus, supra note 5 at 117.

Galambos, supra note 1. 
be founded on breaches of the specific obligations imposed because the relationship is one characterized as fiduciary." ${ }^{\text {39 }}$ In its subsequent focus on the proper recognition of an ad hoc fiduciary relationship, the Court returned to the first principles of fiduciary law applicable to both status and fact-based fiduciary relationships. ${ }^{40}$ In this regard, the Court held that the fiduciary relationship is founded in the requirement of an undertaking to act in the interests of another. ${ }^{41}$ Writing for the unanimous Court, Justice Cromwell clarified the proper approach:

The fiduciary's undertaking may be the result of the exercise of statutory powers, the express or implied terms of an agreement or, perhaps, simply an undertaking to act in this way. In cases of per se fiduciary relationships, this undertaking will be found in the nature of the category of relationship in issue. The critical point is that in both per se and ad hoc fiduciary relationships, there will be some undertaking on the part of the fiduciary to act with loyalty. ${ }^{42}$

Reconciling this new requirement with the principles in Guerin, Frame, and Norberg, ${ }^{43}$ Justice Cromwell explained that the undertaking must be coupled with a resulting discretionary power to affect the legal and practical interests of that other person. He noted that while "[t]he presence of this sort of power will not necessarily on its own support the existence of an ad hoc fiduciary duty; its absence ... negates the existence of such a duty."

On the facts of the case, the Court rejected the argument that a power-dependency relationship alone had given rise to a fiduciary relationship between Galambos and Perez. As there was no undertaking by Galambos to act in Perez's interests in relation to the cash advances, no fiduciary relationship existed. ${ }^{45}$ Furthermore, the Court held that Galambos had no unilateral discretionary power over Perez's interests which could support the imposition of fiduciary duties in the circumstances. ${ }^{46}$

The importance of identifying an undertaking in the recognition of ad hoc fiduciary relationships was reaffirmed by the Supreme Court in Elder Advocates. ${ }^{47}$ This time, in the context of fiduciary duties owed by government, Chief Justice McLachlin held that an undertaking to act in the best interests of a beneficiary would arise only rarely, when required by statute or by implication from the relationship between the parties. ${ }^{48}$ In this case, the Government of Alberta appealed a decision of the Alberta Court of Appeal, which allowed the certification of a class action including claims for breach of fiduciary duty brought by a large class of elderly residents of Alberta's long-term care facilities. The class alleged that the government artificially inflated facility accommodation charges in order to offset the cost of medical expenses. Limiting the application of fiduciary doctrine in the governmental context, the unanimous Court held that "a general obligation to the public ... cannot meet the

Ibid at para 37, referring to Lac Minerals, supra note 11 at 647.

Galambos, ibid at para 77.

Ibid at paras 77-82.

Ibid at para 77 [emphasis added].

Ibid at para 83.

Ibid at para 84 .

Ibid at paras 80-81.

Ibid at paras 84-86.

Supra note 2.

Ibid at paras 45-48. 
requirement of an undertaking." ${ }^{49}$ While the pleadings had emphasized the vulnerability of the class members, they did not establish any express statutory or implied undertaking that would justify the recognition of fiduciary obligations..$^{50}$ As a result of missing this key requirement, the Supreme Court struck the plea of breach of fiduciary duty from the class action. $^{51}$

With the gift of hindsight, the importance of the undertaking as the source of obligation in fiduciary relationships has been a common thread in Canadian jurisprudence. ${ }^{52}$ Initially, Justice Dickson (as he then was) in Guerin provided that fiduciary duties may arise "where by statute, agreement, or perhaps by unilateral undertaking, one party has an obligation to act for the benefit of another." ${ }^{53}$ Borrowing Professor Ernest Weinrib’s definition, ${ }^{54}$ the Court held that whereby the undertaking involved the exercise of discretionary power, the individual empowered would be held to the standard of fiduciary law. ${ }^{55}$ In this sense, "the nature of the relationship [and] not the specific category of actor ... gives rise to the fiduciary duty." ${ }^{56}$ In Norberg, Justice McLachlin (as she then was) held that "[t]he essence of a fiduciary relationship ... is that one party exercises power ... and pledges himself or herself to act in the best interests of the other." 57

The undertaking theory has also been a focus of academic commentary in the common law world. ${ }^{58}$ In 1949, American trusts scholar Austin Scott initially defined a fiduciary as a "person who undertakes to act in the interest[s] of another person" whether the undertaking was mutual or gratuitous. ${ }^{59}$ The Court in Galambos quoted Canadian scholar, Professor Lionel Smith, in articulating that the fiduciary must "relinquish self-interest" by his own act. ${ }^{60}$ Professor John McCamus also viewed the undertaking as both the starting point for the identification of a fiduciary relationship and the principal aspect of the relationship. ${ }^{61}$

The approach taken by the Supreme Court of Canada in Galambos and Elder Advocates has thus been largely supported by commentators as a return to the fundamentals of fiduciary doctrine. ${ }^{62}$ Appreciating the focus of fiduciary law on the relationship between the parties, ${ }^{63}$ vulnerability and fiduciary duties can now be more fully understood as the consequences of

Ibid at para 48.

Ibid at paras 56-59.

Ibid at para 63.

See discussion by Lionel Smith, "Fiduciary Relationships - Arising in Commercial Contexts Investment Advisors: Hodgkinson v. Simms” (1995) 74:4 Can Bar Rev 714 (cited by the Supreme Court of Canada in Galambos, supra note 1 at para 78); James Edelman, "When Do Fiduciary Duties Arise?" (2010) 126 Law Q Rev 302.

53 Guerin, supra note 25 at 384 [emphasis added].

54 Ernest J Weinrib, “The Fiduciary Obligation” (1975) 25:1 UTLJ 1 ("[Where there is a fiduciary obligation] there is a relation in which the principal's interests can be affected by, and are therefore dependent on, the manner in which the fiduciary uses the discretion which has been delegated to him. The fiduciary obligation is the law's blunt tool for the control of this discretion" at 4).

Guerin, supra note 25 at 384.

Ibid.

Norberg, supra note 23 at 272 [emphasis added].

See generally Daniel Bayliss, "Breach of Confidence as a Breach of Fiduciary Obligations: A Theory" (2002) 9:3 Auckland UL Rev 702 at 718-19.

Austin W Scott, “The Fiduciary Principle” (1949) 37:4 Cal L Rev 539 at 540.

Smith, supra note 52 at para 717, cited in Galambos, supra note 1 at para 78 [emphasis omitted].

McCamus, supra note 5 at 122.

Miller, supra note 7 at 261 (further referred to as "the brink of a principled theory of fiduciary liability" at 270); Flannigan, "Fiduciary Accountability," supra note 6 at 432-34, 439.

Galambos, supra note 1 at paras 70-71. 
the fiduciary's undertaking. Vulnerability, in particular, is the natural result of the undertaking and the discretionary power exercised over the beneficiary's legal and practical interests within the relationship. ${ }^{64}$ The duty of loyalty responds to this vulnerability to impose strict standards of conduct on the fiduciary. ${ }^{65}$ Nevertheless, Galambos has been criticized for not further specifying the scope or function of fiduciary obligations arising from the special relationship between the parties, upon which to attribute fiduciary liability ${ }^{66}$ However, as a symbolic and principled approach to a threshold issue in fiduciary law, the focus on the fiduciary's undertaking taken in Galambos and Elder Advocates may provide a preliminary lens through which to consider later issues of fiduciary liability and accountability.

\section{B. FIDUCIARY ACCOUNTABILITY AND THE UNDERTAKING}

Galambos reveals that the existence of an undertaking to act on behalf of another in the exercise of discretion, as the inherent quality of a fiduciary relationship, provides a foundation for the imposition of strict duties on the fiduciary. ${ }^{67}$ Depending on the nature of the undertaking and the specific discretion at the hands of the fiduciary, the scope of fiduciary obligations may include both positive and negative duties. ${ }^{68}$ Starting with the fundamental duty of loyalty, Galambos makes it clear that in "both per se and ad hoc fiduciary relationships, there will be some [express or implied] undertaking on the part of the fiduciary to act with loyalty." ${ }^{\prime \prime 9}$ Developing the scope of this essential undertaking, the fiduciary's duty of loyalty forbids him or her from acting in conflict of interest or from realizing any personal benefit from the fiduciary relationship without the consent of the beneficiary. ${ }^{70}$ Moving through the process, action in the fiduciary's self-interest within the scope of his discretionary power amounts to a breach of the fiduciary duty inherent to his undertaking and triggers remedial rights in the beneficiary. ${ }^{71}$ Breach of fiduciary duty is thus actionable per se without the need for the beneficiary to have suffered a direct harm or loss as a result of the wrongful conduct of the fiduciary ${ }^{72}$ and without regard to the fairness or good faith intentions of the fiduciary. ${ }^{73}$

Pursuant to an action for breach of fiduciary duty, fiduciary law supports a broad remedial scope. ${ }^{74}$ Available remedies include: nominal damages, to symbolically vindicate the rights

at para 84; Rotman, "The Vulnerable Position,” supra note 34 at 67; Mark R Gillen \& Faye Woodman, eds, The Law of Trusts: A Contextual Approach, 2d ed (Toronto: Emond Montgomery, 2008) at 890.

Miller, supra note 7 at 281.

Flannigan, "Fiduciary Accountability," supra note 6 at 445.

Galambos, supra note 1 at paras 70-71; McCamus, supra note 5 at 119; Miller, supra note 7 at 281.

McInerney v MacDonald, [1992] 2 SCR 138 (recognized a positive fiduciary duty on physicians to make medical records available to patients). See also Oosterhoff, supra note 13 at 838.

Galambos, supra note 1 at para 77.

McCamus, supra note 5 at 108; Robert Flannigan, “The Boundaries of Fiduciary Accountability”(2004) NZL Rev 215 at 216-17 [Flannigan, "Boundaries”]; Gautreau, supra note 10 at 7; Irit Samet, "Guarding the Fiduciary’s Conscience - A Justification of a Stringent Profit-stripping Rule” (2008) 28:4 Oxford J Legal Stud 763 at 764.

$71 \quad$ Miller, supra note 7 at 237; Gillen \& Woodman, supra note 64 at 891; Oosterhoff, supra note 13 at 841 42.

Oosterhoff, ibid at 836.

Gautreau, supra note 10 at 7-8. See Boardman v Phipps (1966), [1967] 2 AC 46 (HL (Eng)) [Boardman]; Keech, supra note 12 (liability arises by the mere fact that a benefit was procured regardless of the innocent intentions of the fiduciary).

74 Jeff Berryman, "Equitable Compensation for Breach by Fact-Based Fiduciaries: Tentative Thoughts on Clarifying Remedial Goals” (1999) 37:1 Alta L Rev 95 at 98. 
of the beneficiary; punitive damages, to punish the fiduciary for an outrageous breach; ${ }^{75}$ equitable compensation, to directly address a beneficiary's loss $;{ }^{76}$ and gain-based relief may possibly be available to remove any wrongful gain made by a fiduciary as a result of his breach of duty. ${ }^{77}$ Traditionally, gain-based relief has been available under either a label of "disgorgement" or "restitution" to force the fiduciary to give up any actual gain or enrichment acquired as a result of the breach, irrespective of any loss suffered by the beneficiary. ${ }^{78}$ Gain-based relief is further divided as either a remedy in personam, in the form of a personal judgment for an account of profits made by the fiduciary, or in rem, as a proprietary remedy in the form of a constructive trust over actual assets held by the fiduciary. $^{79}$

In providing an appropriate remedy, fiduciary law seeks to facilitate the maintenance and integrity of the fiduciary relationship in society, ${ }^{80}$ while responding to the nature and consequences of the breach of duty. ${ }^{81}$ The function of the remedy thus remains founded in the goals of the strict fiduciary ethic. Where the primary consequence of the breach is a gain, profit, or benefit by the fiduciary which exceeds any actual or notional loss to the beneficiary, gain-based relief is available. ${ }^{82}$ In these cases, gain-based personal or proprietary relief has been rationalized as supporting either deterrent or restitutionary goals of fiduciary accountability. ${ }^{83}$ However, neither of these understandings of the goals of fiduciary law in the awarding of gain-based remedies is fully satisfactory. ${ }^{84}$

Under the orthodox approach, the gain-based remedy of disgorgement is generally available to provide deterrence in the event of a breach of fiduciary duty. ${ }^{85}$ This deterrence goal was recently applied by the Supreme Court of Canada in Strother v 3464920 Canada Inc, in which a personal account of profits was awarded to serve a "prophylactic purpose," 66 and in Soulos, in the award of a constructive trust "to hold fiduciaries ... [accountable to] high standards of trust and probity." ${ }^{87}$ There has, however, been growing debate and tension in the application of deterrence as a legitimate goal for fiduciary accountability. ${ }^{88}$ In a recent dissenting judgment, Chief Justice McLachlin expressed this concern:

Norberg, supra note 23 (Justice McLachlin (as she then was) and Justice L'Heureux-Dubé held that the plaintiff was entitled to exemplary punitive damages for breach of fiduciary duty at 301). See also Anthony Duggan, "Exemplary Damages in Equity (Punitive Damages for Breach of Fiduciary Obligation)" (Paper delivered at the University of Toronto Law and Economics Workshop Series, 30 November 2005) [Duggan, “Exemplary Damages”].

See Canson Enterprises Ltd v Boughton \& Co, [1991] 3 SCR 534.

Duggan, “Gains-Based Remedies,” supra note 9 at 364.

Berryman, supra note 74 at 98; Oosterhoff, supra note 13 at 844; Duggan, ibid at 365.

Robert Chambers, “Constructive Trusts in Canada” (1999) 37:1 Alta L Rev 173 at 181 [Chambers, “Constructive Trusts”].

Rotman, Fiduciary Law, supra note 5 at 692-93; Gautreau, supra note 10 at 8.

Oosterhoff, supra note 13 at 843-44.

Keech, supra note 12. See also Allen, supra note 16 at 90; Duggan, “Gains-Based Remedies,” supra note 9 at 383; Chambers, "Constructive Trusts,” supra note 79 at 181.

Edelman, "Gain-Based,” supra note 13 at 152; Duggan, "Gains-Based Remedies,” ibid at 365-66.

Duggan, "Gains-Based Remedies," ibid at 384-86.

Keech, supra note 12; Duggan, "Fiduciary Obligations,” supra note 36 at 18; Duggan, "Gains-Based Remedies," ibid at 383.

Supra note 12 at para 75 [emphasis omitted].

Supra note 10 at para 33.

Duggan, "Fiduciary Obligations," supra note 36 at 18; Strother, supra note 12 (identified by Chief Justice McLachlin at para 156). 
Underlying this debate is the tension between the need to deter fiduciaries from abusing their trust on the one hand, and the goal of achieving a remedy that is fair to all those affected, on the other.... Where extra deterrence is required, it is better achieved by remedies such as exemplary damages, which unlike [an] account [of profits], can be tailored to the particular situation. ${ }^{89}$

Where other remedies are available to compensate the beneficiary, the goal of deterrence provides little principled guidance on when gain-based relief should be awarded for a breach. In every case where the fiduciary has received a gain through misuse of his position, deterrence will be an obvious objective for any form of relief that a court is inclined to award. By itself, then, "deterrence” does little to distinguish those cases where a gain-based award may be inappropriate. ${ }^{90}$ Instead, to draw this conclusion, general deterrence must be informed by other principles or considerations, including the potential impact of the award on innocent third parties. The role of other considerations was in fact illustrated by the Supreme Court of Canada's four-part test for the imposition of a constructive trust in Soulos, discussed in more detail below. ${ }^{91}$

Under an alternative approach, gain-based relief has been rationalized as a restitutionary remedy for breach of fiduciary duty. ${ }^{92}$ Restitution is the invariable remedial response to unjust enrichment, where there has been an enrichment of the defendant, a corresponding deprivation to the plaintiff, and an absence of juristic reason to justify the enrichment. ${ }^{93}$ In the context of breach of fiduciary duty, one may view the act of "giving up" a wrongful gain to the beneficiary as "restitution" in response to the enrichment of the fiduciary through his breach. ${ }^{94}$ The goal of restitution is grounded in considerations of corrective justice, avoiding the harsh appearance of deterrence or punishment. ${ }^{95}$ However, where the gain of the fiduciary is made without corresponding loss to the beneficiary, the principle of unjust enrichment as justification for gain-based relief is problematic and unsatisfying. ${ }^{96}$ Under the heading of restitution, we must draw a confusing distinction between a cause of action for unjust enrichment that results from a corresponding gain and deprivation in the traditional sense (subtractive unjust enrichment), and "unjust enrichment” on the basis of wrongdoing alone (unjust enrichment by wrongdoing). ${ }^{97}$

While capturing debate in the context of the availability of gain-based relief generally, the remedial goals of deterrence and restitution have specifically resulted in a distorting of the traditional availability of a constructive trust as proprietary gain-based relief for breach of fiduciary duty. ${ }^{98}$ Through the parallel development and expansion of the constructive trust

Strother, ibid.

Duggan, "Gains-Based Remedies,” supra note 9 at 379.

Soulos, supra note 10 at para 45.

Jason Brock, “The Propriety of Profitmaking: Fiduciary Duty and Unjust Enrichment” (2000) 58:2 UT Fac L Rev 185 at 188.

$93 \quad$ Pettkus v Becker, [1980] 2 SCR 834 at 848 [Pettkus]; McInnes, supra note 16 at 518; Lionel D Smith et al, The Law of Restitution in Canada: Cases, Notes, and Materials (Toronto: Emond Montgomery, 2004) at 81.

94 Brock, supra note 92 at 188; Francesco Giglio, “Restitution for Wrongs: A Structural Analysis” (2007) 20:1 Can JL \& Jur 5 at 6.

Duggan, “Gains-Based Remedies,” supra note 9 at 365.

Chambers, "Constructive Trusts," supra note 79 at 180; Craig Rotherham, "Restitution and Property Rites: Reason and Ritual in the Law of Proprietary Remedies” (2000) 1 Theor Inq L 205 at 205.

Duggan, “Gains-Based Remedies,” supra note 9 at 365.

McCamus, supra note 5 at 118; Oosterhoff, supra note 13 at 827; Duggan, “Gain-Based Remedies,” ibid at 265. 
in Canadian law, it is clear that while both deterrence and restitution for unjust enrichment have some place in rationalizing the availability of proprietary gain-based relief, neither of these explanations can provide an independent, principled approach to explain the use of a constructive trust in response to a breach of fiduciary duty.

\section{PRoprietary ReMEdY FOR BREACH OF FidUCIARY DUTY - THE CONSTRUCTIVE Trust}

Application of the constructive trust dates back to the seventeenth century. ${ }^{99}$ In its traditional conception as a trust imposed by law, the constructive trust was established as a substantive institution which could be employed to force the conveyance of property belonging in equity to the plaintiff. ${ }^{100}$ In this regard, the constructive trust operated like other trusts, requiring the person in possession to hold the subject matter of the trust for the benefit of another. ${ }^{101}$ Recognizing equitable property rights in the beneficiary, the constructive trust is a powerful gain-based remedy, allowing the beneficiary to identify his property as among the assets of the fiduciary and trace the location of value through substitutions of the asset. ${ }^{102}$ As a result, the beneficiary enjoys priority in the case of the insolvent fiduciary and receives the benefit of any increase in value of the asset. ${ }^{103}$ Marginally, the recognition of a constructive trust also neatly avoids the complex task of evaluating the gain or benefit acquired by the fiduciary as a result of his or her breach of duty. ${ }^{104}$

Although applied in a variety of situations, ${ }^{105}$ the institutional constructive trust was most commonly employed as a vehicle "to compel the disgorgement of a [proprietary] benefit ... acquired through breach of fiduciary duty,” in an award for proprietary gain-based relief. ${ }^{106}$ Where the consequence of the breach of fiduciary duty was the accrual of some asset or property to the fiduciary and a proprietary remedy was deemed appropriate in the circumstances, ${ }^{107}$ a constructive trust could be imposed to redress the instant breach, deter future breaches, and enforce the fiduciary's utmost duty of loyalty to his beneficiary. ${ }^{108}$

Holt $v$ Holt (1670), 22 ER 756 (involving a testamentary trust and lease renewal which was to be held for the benefit of the testator's children as beneficiaries of the will). See also DWM Waters, The Constructive Trust: The Case for a New Approach in English Law (London: University of London, 1964) at 39.

Stuart Hoegner, "How Many Rights (or Wrongs) Make a Remedy? Substantive, Remedial and Unified Constructive Trusts” (1997) 42:2 McGill LJ 437 at 440, 442; McInnes, supra note 16 at 521. Rev 133 at 164 [Rotman, "Deconstructing the Constructive Trust"].

Malcolm Cope, "A Comparative Evaluation of Developments in Equitable Relief for Breach of Fiduciary Duty and Breach of Trust” (WA Lee Equity Lecture Series, delivered at the Faculty of Law, Queensland University of Technology, 27 October 2005), (2006) 6:1 Queensland University of Techology Law \& Justice Journal 118 at 143; Gillen \& Woodman, supra note 64 at 525 . See Boscawen v Bajwa, [1996] 1 WLR 328 (CA) (further discussion of tracing rules per Lord Justice Millett at 335-38). Gillen \& Woodman, ibid at 526; Oosterhoff, supra note 13 at 1208-209.

Alderson, supra note 20 at 256.

McInnes, supra note 16 (under the institutional approach, a constructive trust could also be activated in a grab bag of other fixed categories of situations including the "(i) inequitable acquisitions of property inter vivos, (ii) inequitable acquisitions of property upon death, (iii) acquisitions of property by murder, ... or (v) mistaken payments” at 522 [footnotes omitted]).

Oosterhoff, supra note 13 at 827.

Chambers, "Constructive Trusts," supra note 79 at 181.

Boardman v Phipps, supra note 73; Reid, supra note 14; Hoegner, supra note 100 at 442; Duggan, "Constructive Trusts,” supra note 12 at 217; Gillen \& Woodman, supra note 64 at 527. 
Prior to the 1980s, the law of constructive trusts in Canada mirrored this traditional substantive approach, ${ }^{109}$ enforcing and vindicating property rights held by the plaintiff in equity. ${ }^{110}$ By the 1980 s, however, Canadian courts had begun to search for new remedial solutions to property disputes between spouses and cohabiting partners. ${ }^{111}$ In a significant broadening of the law of constructive trusts, the Supreme Court of Canada in Pettkus recognized that a remedial constructive trust could be awarded as proprietary equitable relief in the absence of any special relationship between the parties. ${ }^{112}$ In these circumstances, the constructive trust responded directly to the unjust enrichment of one party by another, creating property rights as a remedial measure. ${ }^{113}$ From this point, the constructive trust was increasingly viewed singly as a remedy against unjust enrichment in all its applications. ${ }^{114}$

In the decades since Pettkus, Canadian courts have reaffirmed the remedial nature of the constructive trust generally. ${ }^{115}$ Nevertheless, clear confusion has resulted from the seemingly principled restitutionary approach. ${ }^{116}$ The cause of action for unjust enrichment, as considered in Pettkus, is based on the corresponding deprivation of the plaintiff as a result of the defendant's gains. ${ }^{117}$ From this solely subtractive definition, the principle of unjust enrichment simply cannot justify all appropriate cases for the award of a constructive trust. ${ }^{118}$ In the context of fiduciary law in particular, a claim for breach of fiduciary duty does not require the beneficiary to show any corresponding loss to trigger remedial action. ${ }^{119}$ Thus, describing a proprietary gain-based remedy as "restitution" causes initial confusion in the underlying claim for breach of fiduciary duty as a cause of action for subtractive unjust enrichment. ${ }^{120}$ In the fiduciary context, the "unjust enrichment" of the fiduciary may be better understood as wrongdoing alone, on the basis of a notional or normative loss to the beneficiary as a result of a fiduciary's breach of duty. ${ }^{121}$ In this sense, the enrichment of the fiduciary is wrongful or unjust in and of itself, ${ }^{122}$ just as breach of fiduciary duty is considered actionable per se without any proof of loss to the beneficiary. ${ }^{123}$ Under this broader approach of unjust enrichment by wrongdoing, the constructive trust may appropriately serve a "restitutionary" purpose as proprietary gain-based relief in appropriate

Keith B Farquhar, "Unjust Enrichment and Constructive Trust: Comment on Korkontzilas v. Soulos," Case Comment, (1997) 31:2 UBC L Rev 341 at 342-43.

Rotherham, supra note 96 at 226; Goode, supra note 15 at 221.

Rotman, "Deconstructing the Constructive Trust," supra note 101 at 134 . See also Murdoch v Murdoch, [1975] 1 SCR 423; Rathwell v Rathwell, [1978] 2 SCR 436.

Pettkus, supra note 93; Hoegner, supra note 100 at 444; Farquhar, supra note 109 (under the traditional institutional approach, the constructive trust was viewed as enforcing the pre-existing property rights of the plaintiff, and did not "create" property rights as a remedial measure at 348); MM Litman, "The Emergence of Unjust Enrichment as a Cause of Action and the Remedy of Constructive Trust” (1988) 26:3 Alta L Rev 407 (elevating the principle of unjust enrichment to a full cause of action at 408).

Pettkus, ibid at 848-49; Farquhar, ibid at 348-49; recently affirmed by the Supreme Court of Canada in Kerr v Baranow, 2011 SCC 10, [2011] 1 SCR 269 [Kerr].

Pettkus, ibid (the principle of unjust enrichment was seen to lie "at the heart of the constructive trust" at 847); Duggan, "Gains-Based Remedies," supra note 9 at 366; McInnes, supra note 16 at 524; Hoegner, supra note 100 at 448-49.

Hoegner, ibid at 444-46; McInnes, ibid at 523. See Kerr, supra note 113; Peter v Beblow, [1993] 1 SCR 980; Lac Minerals, supra note 11; Hunter Engineering Co v Syncrude Canada Ltd, [1989] 1 SCR 426. Chambers, "Constructive Trusts,” supra note 79 at 180; Rotherham, supra note 96 at 205; McInnes, ibid at 527 .

Pettkus, supra note 93 at 835; Kerr, supra note 113 at para 50; Duggan, “Gains-Based Remedies,” supra note 9 at 366.

McInnes, supra note 16 at 527; Litman, supra note 112 at 410.

Giglio, supra note 94 at 6; McInnes, supra note 16 at 520.

Chambers, "Constructive Trusts," supra note 79 at 179; Smith, supra note 93 at 403.

Brock, supra note 92 at 194.

Duggan, “Gains-Based Remedies,” supra note 9 at 365.

Oosterhoff, supra note 13 at 836. 
circumstances. ${ }^{124}$ Nevertheless, the distorting and confusing effect of the terms of "unjust enrichment" and "restitution" in the context of fiduciary wrongdoing is evident from the Supreme Court of Canada's decision in Lac Minerals. ${ }^{125}$

In Lac Minerals, a junior mining company, International Corona Resources Ltd (Corona), entered into joint venture negotiations with a more senior mining company, Lac Minerals Ltd (Lac Minerals), to acquire mining rights to specific property for excavation of mineralbearing deposits. In the course of negotiations, Corona provided Lac Minerals with information regarding its identification of gold deposits in its initial testing of the lands. When negotiations broke down, Lac Minerals instituted a successful competing bid to acquire the mining rights. Lac Minerals ultimately developed a productive gold mine on the land of its own initiative. In a confusing majority division, ${ }^{126}$ the Supreme Court of Canada found that while no fiduciary relationship arose on the facts as between the two arm's-length companies, a constructive trust was the most appropriate relief for a wrongful breach of confidence by Lac Minerals. Thus, Lac Minerals was found to hold the property and the mine on constructive trust for the benefit of Corona. In providing this sweeping relief, the majority opinion on remedy, by Justice La Forest, held that a constructive trust was available on the satisfaction of the elements of a cause of action for subtractive unjust enrichment. ${ }^{127}$ However, as the basis for relief in this case was a wrongful act, either in the form of breach of confidence or breach of fiduciary duty, the subsequent superimposition of the three requirements of an action for subtractive unjust enrichment resulted in a tortured analysis by Justice La Forest to reach a justification for the imposition of a remedial constructive trust. ${ }^{128}$

The limitations of the exclusively remedial approach to the constructive trust were finally addressed in 1997 by the Supreme Court of Canada in Soulos. ${ }^{129}$ In this case, a real estate broker entered into negotiations for the purchase of commercial building on behalf of an interested purchaser. Eventually, believing the property to be of good value, the real estate agent offered the seller his asking price in his personal capacity and transferred title to the property in his wife's name upon execution of the purchase. The agent then told his purchaser that the property was no longer available. Upon realizing this deception, the purchaser brought an action for breach of fiduciary duty, seeking a declaration that the commercial property was held on constructive trust by the agent's wife for his benefit.

Following the recognition of a fiduciary agent-principal relationship, it would notionally seem that the fiduciary in this case acquired a benefit at the expense of the interests of his beneficiary, by acquiring an opportunity personally in the place of his principal. These facts

Brock, supra note 92 at 188; Duggan, "Gains-Based Remedies,” supra note 9 at 365; Chambers, "Constructive Trusts," supra note 79 at 179; Robert Chambers, "The Consequences of Breach of Fiduciary Duty” (2005) 16:1 The King’s College Law Journal 186 at 194 [Chambers, “Consequences”]; McInnes, supra note 16 at 518.

125 Lac Minerals, supra note 11.

126 Ibid (both Justice La Forest and Justice Wilson found a breach of fiduciary duty and a breach of confidence, and held that the remedy should be the same for either and both breaches — a constructive trust over the property acquired by Lac Minerals; Justice Lamer agreed with Justice La Forest on the remedy for the action of breach of confidence; Justices Sopinka and McIntyre, in the minority, held that a damages award was appropriate in the circumstances, for breach of confidence). Ibid (per Justice La Forest, requiring proof of an enrichment, a corresponding deprivation, and an absence of a juristic reason for the enrichment at 668-70, 674-78). 
are thus initially consistent with the proposition that the fiduciary agent had been unjustly enriched in a subtractive sense, as required under Justice La Forest's Lac Minerals analysis. ${ }^{130}$ However, this analysis was frustrated by the fact that the property had actually dropped in value since its acquisition by the agent. No monetary profit had been made by the fiduciary. In her majority judgment in Soulos, Justice McLachlin (as she then was) held that the availability of a constructive trust must be viewed beyond the requirements of a cause of action for subtractive unjust enrichment as applied in Pettkus. ${ }^{131}$ Returning to the historical availability of the institutional constructive trust as deterrence-focused proprietary gain-based relief, the majority held that the constructive trust would be "imposed for breach of fiduciary relationship[s] ... to hold fiduciaries and people in positions of trust [accountable] to the high standards of trust and probity."132

In another attempt to unify the principled application of the constructive trust under the goals of equity, the majority held that a constructive trust would be awarded where "[g]ood conscience" requires, in all situations of a wrongful gain and/or unjust enrichment. ${ }^{133}$ In this regard, the constructive trust could respond principally to either cause of action, serving a deterrent purpose in response to a wrongful gain alone or a restitutionary objective to reverse the unjust enrichment of a defendant. In assessing the availability of a constructive trust as proprietary gain-based relief for the instant case of breach of fiduciary duty, Justice McLachlin applied the concept of "good conscience" through criteria borrowed from Professor Roy Goode’s essay, "Property and Unjust Enrichment.”134 Good conscience will support gain-based relief in the form of a constructive trust where:

(1) The defendant [is] under an equitable obligation ... in relation to the activities giving rise to the assets in his hands;

(2) The assets in the hands of the defendant [are] shown to have resulted from deemed or actual agency activities of the defendant in breach of his equitable obligation to the plaintiff;

(3) The plaintiff [can] show a legitimate reason for seeking a proprietary remedy ... and;

(4) There [are] no factors which would render imposition of a constructive trust unjust in all the circumstances ... [including protection of the interests of intervening creditors]. ${ }^{135}$

In dissent, Justice Sopinka emphasized the requirement of a monetary profit and unjust enrichment of the fiduciary for the availability of gain-based relief in any form. On the facts of the case, the fiduciary did not acquire any monetary gain from his purchase of the property; therefore, there was no unjust enrichment and "the beneficiary [did] not have a right to a remedy."136 In Justice Sopinka’s view, deterrence alone could not justify the 
availability of gain-based relief and could not therefore permit the order of a constructive trust. $^{137}$

With this debate between the members of the Court, Soulos provides an important opportunity to reflect on the conceptual connections between the goals of fiduciary law in providing gain-based relief, unjust enrichment, and the constructive trust. However, the Supreme Court of Canada's rejection of a required cause of action in unjust enrichment for the provision of a constructive trust for breach of fiduciary duty was not necessary on the facts of the case. From the normative view of unjust enrichment by wrongdoing, the acquisition of a title to real property by the agent in Soulos constituted an "enrichment" or gain which could be remedied by principled proprietary restitution as gain-based relief. ${ }^{138} \mathrm{At}$ the same time, it was clear that the agent breached his fiduciary duty by acting in self-interest and acquiring the property per se. The award of a constructive trust as proprietary gain-based relief in this case thus arguably served both restitutionary and deterrence purposes in protecting the integrity of the underlying fiduciary relationship. ${ }^{139}$ In fact, as no pecuniary gain was made by the fiduciary in this case, a proprietary constructive trust was the only way by which the Court could award gain-based relief and effectively vindicate the higher objective of upholding trust and confidence in fiduciary relationships.

\section{Perfecting the Fiduciary Undertaking}

The individual conceptual goals of deterrence and restitution may serve to justify the availability of proprietary gain-based relief for breach of fiduciary duty in appropriate circumstances. ${ }^{140}$ As shown in Soulos, these objectives are not mutually exclusive. ${ }^{141}$ Alone, however, neither of these policy objectives can principally rationalize the availability of appropriate gain-based relief or the specific imposition of a constructive trust for breach of fiduciary duty. In some cases, the goal of reversing unjust enrichment has been applied to justify forcing the fiduciary to give up his wrongful gain. ${ }^{142}$ However, where the breach of duty gives rise to an asset in the hands of the fiduciary, in the absence of a pecuniary enrichment of the fiduciary or in the absence of a corresponding loss to the beneficiary, the cause of action of unjust enrichment cannot satisfactorily explain the imposition of proprietary gain-based relief. In Soulos, this conceptual problem led the majority to reaffirm the continued institutional availability of the constructive trust to deter wrongful fiduciary acts. ${ }^{143}$ In many cases of fiduciary breach, it is natural to consider the aim of a gain-based remedy as prophylactic protection of fiduciary relationships. ${ }^{144}$ However, the aim of deterrence alone is too broad and nebulous to function as a formula for the imposition of proprietary gain-based relief. Rather, this determination must be informed by other considerations, as set out in Soulos. ${ }^{145}$

\footnotetext{
$137 \quad$ Ibid at para 75.

$138 \quad$ McInnes, supra note 16 at 535; Brock, supra note 92 at 202.

139 McInnes, ibid.

140 Duggan, "Gains-Based Remedies,” supra note 9 at 384.

141 Chambers, “Consequences,” supra note 124 at 194.

Lac Minerals, supra note 11 at 668-70, 674-78.

Soulos, supra note 10 at para 33, citing Hodgkinson, supra note 12 at 453.

See Soulos, ibid; Boardman, supra note 73; Keech, supra note 12.

Soulos, ibid at para 45.
} 
Following and expanding the Galambos approach to fiduciary relationships, I suggest that the enforcement of the undertaking of the fiduciary should be viewed as a principled objective through which to justify the availability of proprietary gain-based relief for breach of fiduciary duty. ${ }^{146}$ Overcoming political and conceptual problems with the goals of deterrence and restitution, this proposal serves to provide a principled equitable basis through which a constructive trust might be awarded to support the broad recognition of the fiduciary relationships and available remedy, ${ }^{147}$ while usefully emphasizing the undertaking as the principled focus in reaching this objective. To illustrate, I apply this proposal in the context of three examples of undertakings and fiduciary breach, lying on a spectrum of predictable availability of a constructive trust, where the consequence of the breach of fiduciary duty is the accrual of some property into the hands of the fiduciary. Flowing from this analysis, and heeding the traditional maxim of equity, equity deems to be done what ought to be done, ${ }^{148}$ a constructive trust as proprietary gain-based relief should be available where it is necessary or possible to enforce the undertaking of the fiduciary. Underlying this analysis, each case must be approached according to its own internal logic, through an appreciation of the nature of the undertaking made by the fiduciary and the consequences of the breach of duty.

\section{A. SPECTRUM OF UNDERTAKINGS}

\section{UNDERTAKING OF AN EXPRESS TRUST}

Starting from the archetypal example of a fiduciary undertaking in an express trust, the undertaking of the fiduciary trustee is to hold specific property for the benefit of the beneficiary. In the event of a breach of the undertaking through which the fiduciary appropriates the property to his own name in a breach of trust, the beneficiary has been directly deprived of his or her equitable rights in the property. ${ }^{149}$ If the fiduciary trustee has retained the property in some traceable form or it can be followed into the hands of a donee, the beneficiary will be entitled to recover the property itself through the imposition of a constructive trust. ${ }^{150}$ Regardless of the monetary value of the property or the monetary loss of the beneficiary as a result of the breach, the constructive trust can be seen to enforce or extend the initial express trust arrangement. ${ }^{151}$

In the context of an express trust, the beneficiary's entitlement to a proprietary remedy need not be derived from the fiduciary regulation of trustees but is a direct extension of the beneficiary's proprietary interest under the law of trusts. Nevertheless, for the purposes of perspective, the express trust serves as an archetypal example at the uncontroversial extreme of our understanding of breach of a fiduciary undertaking and the availability of proprietary gain-based relief. From the traditional positions, the constructive trust may be justified on the basis of unjust enrichment of the fiduciary by subtractive retention of the trust property

Duggan, "Constructive Trusts," supra note 12 (consideration of the perfectionary function of a constructive trust generally from a law and economics perspective). See Lysaght $v$ Edwards (1876), 2 Ch D 499 (perfectionary constructive trust illustrated in applications outside of fiduciary law, e.g. the specific enforcement of contracts for the sale of land).

McCamus, supra note 5 at 115 .

Reid, supra note 14 at 331.

Oosterhoff, supra note 13 at 1159-61.

Ibid at 1208-209.

Cope, supra note 102 at 143. 
or on the basis of deterring this fundamental breach of trust. Alternatively, under the suggested approach, we may examine the undertaking of the fiduciary directly. In the express trust example, the relevant undertaking is itself based on a property interest. Therefore, where the property has been wrongfully acquired and traceably retained by the fiduciary, proprietary gain-based relief in the form of a constructive trust is necessary to enforce the undertaking of the fiduciary. The constructive trust operates as a vehicle to specifically enforce the undertaking of the trustee to hold the property for the benefit of the beneficiary. This approach recognizes the availability of proprietary gain-based relief as a right to the beneficiary in line with a traditional doctrinal approach of trusts law. ${ }^{152}$

\section{UNDERTAKING OF AGENCY}

More equivocally, as on the facts of Lac Minerals ${ }^{153}$ and Soulos, ${ }^{154}$ proprietary gain-based relief may be available even where the beneficiary has no direct proprietary interest at the outset of the fiduciary relationship. This situation may be captured in the basic agency relationship. As an agent, the fiduciary has broadly undertaken to act in the interests of the beneficiary in the pursuit of some opportunity on his or her behalf. The undertaking in this context does not include any initial property rights held by the beneficiary. However, through the operation of the agency relationship and acquisition of the opportunity, property rights could be acquired in the interests of the beneficiary. Conversely, property rights could be acquired in the personal interests of the fiduciary in breach of his or her fiduciary undertaking.

Even where property has accrued to the fiduciary as a result of his breach of fiduciary duty in this respect, there may not be a monetary profit realized by the fiduciary on which to base an award of "restitution" for unjust enrichment. ${ }^{155}$ Similarly, we may not wish to impose a strictly deterrent goal to compel the specific disgorgement of the fiduciary's wrongful gain. ${ }^{156}$ Alternatively, however, we may justify the availability of proprietary gain-based relief by looking to the undertaking of agency assumed by the fiduciary in this context. Taking the approach in Soulos and adopting Professor Goode's thesis, proprietary gain-based relief may flow where property is acquired through the deemed agency of the fiduciary. ${ }^{157}$ "Deemed agency gains" 158 are then defined in this context as gains which are derived from the activity undertaken by the fiduciary in his own benefit, which should have been acquired for the benefit of the beneficiary. Equity will deem done what should have been done, ${ }^{159}$ and property that should have been acquired for the beneficiary may be declared to be held for the benefit of the beneficiary through the imposition of the constructive trust. From this approach, the constructive trust may function as a corrective arrow in the quiver of the

Subject to the usual discretion of equity (e.g. where the beneficiary arrives with unclean hands). See Oosterhoff, supra note 13 at 1209; Litman, supra note 112 at 454.

Lac Minerals, supra note 11 (minority recognition of a fiduciary relationship).

Soulos, supra note 10.

As in Soulos, ibid.

Strother, supra note 12, McLachlin CJC, dissenting in part; Lac Minerals, supra note 11 (breach alone is not enough, need to establish unjust enrichment, per Justice La Forest at 672-73).

Soulos, supra note 10 (requires that "[t]he assets in the hands of the defendant ... be shown to have resulted from deemed or actual agency activities of the defendant in breach of his equitable obligation to the plaintiff" at para 45).

Goode, supra note 15 at 219.

Reid, supra note 14 at 331. 
court's equitable jurisdiction to enforce the undertaking of the fiduciary to pursue the acquisition of property in the interests of the beneficiary.

Nevertheless under Soulos, proprietary relief is not available as of right to the wronged principal. The beneficiary must also establish "a legitimate reason for seeking a proprietary remedy," and that there are "no factors which would render imposition of a constructive trust unjust in all of the circumstances," including protection of the interests of intervening creditors. ${ }^{160}$ With this qualification in mind, a constructive trust will be available in discretionary circumstances as it is possible to specifically enforce the undertaking of the fiduciary to have acquired the property on behalf of the beneficiary.

\section{UNDERTAKING OF LOYALTY}

As defined in Galambos, every fiduciary must have expressly or impliedly undertaken to act in the interests of the beneficiary. ${ }^{161}$ Pursuant to this undertaking, fiduciary law recognizes the general duty of loyalty owed by the fiduciary to act selflessly in the scope of his or her duty to promote the interests of the beneficiary. ${ }^{162}$ The receipt of a bribe or a secret profit/commission in the course of acting in a fiduciary capacity constitutes an egregious breach of this fundamental duty of loyalty owed to the beneficiary. ${ }^{163}$ On the criminal side, both the briber and fiduciary may be held criminally responsible for a corrupt payment. ${ }^{164}$ Furthermore, the beneficiary has traditionally been able to compel disgorgement of the bribe itself or the value of the bribe as reparation for breach of fiduciary duty. ${ }^{165}$ In this example, the availability of proprietary gain-based relief to compel the giving up of a bribe acquired by a fiduciary lays at the most controversial end of the undertaking spectrum.

Historically, English equity drew a distinction between monetary and property-based bribes for the availability of a proprietary gain-based remedy, holding that where a bribe was received in the form of property and traceably survived, the beneficiary was entitled to demand gain-based relief through a constructive trust. ${ }^{166}$ This rule was mostly overturned, however, by the Privy Council in A-G for Hong Kong v Reid, ${ }^{167}$ in an appeal from the Court of Appeal of New Zealand. In Reid, the Director of Public Prosecutions of Hong Kong, Mr. Reid, had accepted large monetary bribes in breach of his fiduciary duty of loyalty as a servant of the Crown. The proceeds were subsequently used by Reid to purchase several properties in New Zealand. In an action for breach of fiduciary duty, the Government of Hong Kong sought proprietary gain-based relief and a declaration that the New Zealand properties were held on constructive trust for the benefit of the Crown. Focusing on the wrongful benefit acquired by the fiduciary as a result of his egregious breach of loyalty, Lord Templeman held that effective deterrence of this conduct required that a gain-based remedy capture all traceable proceeds of the bribe. ${ }^{168}$ Stressing this point, Lord Templeman stated,

Soulos, supra note 10 at para 45; Goode, supra note 15 at 240.

Galambos, supra note 1 at para 77.

Miller, supra note 7 at 259.

Oosterhoff, supra note 13 at 882.

Criminal Code, RSC 1985, c C-46, ss 119-25, 139, 426; Oosterhoff, ibid at 883.

Reading v Attorney-General, [1951] AC 507 (HL (Eng)) [Reading]; Lister \& Co v Stubbs (1890), 45 Ch

D 1 (CA) [Lister]; Reid, supra note 14 at 330; see also Oosterhoff, ibid at 883-87.

Lister, ibid; Oosterhoff, ibid at 884.

Supra note 14 . See Allen, supra note 16 at 87.

Reid, ibid at 330-31. 
"[b]ribery is an evil practice which threatens the foundations of any civilised society."169 Accordingly, the New Zealand properties were declared to be held on constructive trust for the benefit of the Crown from the moment they were acquired by Reid.

The issue of recovery of bribes through proprietary gain-based relief for breach of fiduciary duty has yet to be addressed directly under Canadian fiduciary law. ${ }^{170}$ Although the English case law on point has not been directly adopted, the relevant line of cases has been approved by the Supreme Court of Canada in the context of supporting the application of fiduciary law to protect the practical or moral interests of a beneficiary. ${ }^{171}$ While the Canadian approach would thus traditionally agree with the result in Reid, "that a fiduciary must not be allowed to benefit from his own breach of duty" in any way, ${ }^{172}$ it is unclear how Canadian courts would principally support the availability of proprietary gain-based relief in this situation. From the objective of reversing unjust enrichment, bribe-taking is a paradigm case of breach of fiduciary duty without subtractive unjust enrichment. ${ }^{173}$ While the fiduciary has likely been "enriched" by the bribes, the beneficiary has not suffered any corresponding deprivation other than a notional loss based on the breach of loyalty. ${ }^{174}$ Traditionally, then, gain-based relief would be understood to serve a solely deterrent and punitive objective to redress the "guilty criminal purpose"175 of the fiduciary's gain. If deterrence is used as a singular objective, anytime that the value of property retained through the breach of duty is greater than the monetary value of the bribe, a constructive trust would be awarded to disgorge the entirety of the benefit acquired by the fiduciary ${ }^{176}$ regardless of the interests of third-party creditors or other considerations. ${ }^{177}$

Alternatively, under my proposal, Canadian fiduciary law can rationalize the possible availability of proprietary gain-based relief for bribe-taking on the basis of proper enforcement of the fiduciary's undertaking. In this regard, two different perspectives may be taken on the undertaking of the fiduciary. These avenues reflect tension between a conservative agency approach ${ }^{178}$ and the broader objective to uphold the integrity of fiduciary relationships in society. ${ }^{179}$

First, our analysis can follow the Soulos test and focus on the particular absence of an undertaking of agency by the fiduciary in receiving the bribes. ${ }^{180}$ The undertaking of a fiduciary to act in the interests of the beneficiary does not include a duty to transmit bribes

\section{Reid, ibid at 330.}

Duggan, “Gains-Based Remedies,” supra note 9 at 372.

Frame, supra note 28 (recognized as examples of fiduciary law protecting more than just legal interests of a vulnerable beneficiary at 137; reaffirmed in Norberg, supra note 23 at 274-76).

Reid, supra note 14 at 336.

Duggan, "Gains-Based Remedies," supra note 9 at 384.

Brock, supra note 92 at 194.

Reid, supra note 14 at 332. See also Duggan, “Gains-Based Remedies,” supra note 9 at 384.

Reid, ibid at 336

Ibid (in the opinion of the Court, the creditors cannot stand in a better position than their debtor, who was deemed to hold the bribe and secondary property acquired with the bribe proceeds on trust for the beneficiary from the moment the bribes were received at 331).

Soulos, supra note 10 at para 33. See also Goode, supra note 15.

Soulos, ibid.

Ibid (the application of a constructive trust to support the "good conscience" of the fiduciary requires that the assets acquired by the fiduciary be obtained by deemed or actual agency activities through the breach of duty at para 45). 
received in the position of fiduciary to the beneficiary as a "deemed agency gain."181 Equity will deem done what ought to be done, ${ }^{182}$ but the fiduciary should never have received the bribe in the first place. From this negative analysis, the beneficiary is arguably not entitled to gain-based relief in personal or proprietary form in the enforcement of the fiduciary undertaking. This approach is not consistent with the traditional position in equity as it does not remove all wrongful profits from the fiduciary as a result of his breach. ${ }^{183}$ However, if the Supreme Court of Canada concludes that deterrence should no longer independently support the availability of any gain-based relief for breach of fiduciary duty, ${ }^{184}$ this approach can principally limit the role of fiduciary law in punishing and deterring bribe-taking. In this sense, fiduciary law would allow the appropriate application of criminal law to impose deterrent and punitive sanctions on fiduciaries for this behaviour. ${ }^{185}$ In fact, in Reid the fiduciary was already serving an eight-year sentence for offences under the Prevention of Bribery Ordinance. ${ }^{186}$

However, given the fundamental importance of the no-profit rule in Canadian fiduciary law, ${ }^{187}$ the need to protect the moral interest of the beneficiary against the deliberate wrongful acts of the fiduciary, ${ }^{188}$ and the likely inclination of Canadian courts in this context, alternative reinforcement of the availability of proprietary gain-based relief in this context is necessary. More appropriately, therefore, principled enforcement of the undertaking in the context of bribes should focus on the positive undertaking of loyalty made by the fiduciary. By promising to act in the interests of the beneficiary, the fiduciary has undertaken to act with utmost loyalty and faithfulness in his or her position. ${ }^{189}$ In accepting a bribe, the fiduciary has in effect accepted an inducement to betray the trust owed to the beneficiary. ${ }^{190}$ From my proposal, then, enforcement of the fiduciary undertaking requires a vindication of this loyalty, which has been wrongfully violated by the receipt of the bribe, through the provision of gain-based relief. Although this approach closely spirals to a deterrent objective, it focuses on the objective of supporting the trust and confidence placed in the fiduciary relationship rather than the punishment of the fiduciary for his wrongful act. Principally from this position, where receipt of the bribe has resulted in the accrual of traceable property to the fiduciary, a proprietary remedy may be available as gain-based relief to effectively support the undertaking of loyalty. As in an undertaking of agency, an award of a constructive trust is one possible way through which the undertaking of the fiduciary may be perfected or enforced. Conservatively then, a constructive trust should be imposed on the same limiting criteria delineated in Soulos - where the beneficiary has a "legitimate reason for seeking proprietary" relief and considering the impact of a constructive trust on the interests of third parties. ${ }^{191}$ This approach allows the court to rationally provide gain-based relief to enforce the undertaking of loyalty assumed by the fiduciary while leaving the

Ibid.

Reid, supra note 14 at 331.

Reid, ibid; Reading, supra note 166; Lister, supra note 166.

Soulos, supra note 10 (minority decision at paras 53-82); Strother, supra note 12 (minority decision at paras 117-65).

Duggan, "Exemplary Damages," supra note 75 at 34.

Reid, supra note 14 at 330.

See Hodgkinson, supra note 12; Canadian Aero Service Ltd v O'Malley (1973), [1974] SCR 592.

As specified in Frame, supra note 28 at 136-37.

Miller, supra note 7 at 256-57.

Reid, supra note 14 at 330.

Soulos, supra note 10 at para 45. 
ultimate award of a constructive trust as discretionary in consideration of the impact on thirdparty creditor interests.

\section{ConClusions}

The unprincipled development of fiduciary doctrine and the law of proprietary remedies have led to considerable confusion in the availability of gain-based proprietary remedies for breach of fiduciary duty. By renewing focus in fiduciary law on the relationship between the parties and the undertaking of the fiduciary to act in the interests of the beneficiary, the Supreme Court of Canada in Galambos and Elder Advocates has started on a path towards the principled application of fiduciary theory. ${ }^{192}$ In order to reach full explanatory power in this regard, the Galambos approach can be elaborated beyond the initial identification of a fiduciary relationship, towards a broader appreciation of fiduciary accountability in the context of gain-based relief. ${ }^{193}$

In this article, I have argued that by extending the Galambos approach and heeding the traditional equitable maxim, equity deems to be done what ought to be done, the constructive trust may be principally available as proprietary gain-based relief for breach of fiduciary duty where it is possible to enforce the fiduciary's undertaking through a proprietary remedy. As illustrated by three example undertakings, where a breach of fiduciary duty has resulted in a property gain by the fiduciary, the familiar goals of deterrence or restitution for unjust enrichment have generated confusion and uncertainty in the availability of proprietary gainbased relief. Avoiding the debate and terminology struggle between deterrence, disgorgement, unjust enrichment, and restitution, the proposed policy objective of perfecting and enforcing the undertakings of fiduciaries can effectively rationalize the availability of proprietary gain-based relief in these situations while supporting the underlying purpose of fiduciary law, to facilitate the maintenance and integrity of relationships of trust and confidence in society. Applying this proposal, where a proprietary remedy is necessary to enforce the undertaking of the fiduciary as a trustee, the constructive trust is available as of right to the beneficiary. From this non-contentious point, I argue that where a proprietary remedy can be awarded to specifically enforce an undertaking of agency or loyalty, the constructive trust should be available as a discretionary remedy considering the interests of the beneficiary and third-party creditors.

This proposal and analysis does not purport to provide an exhaustive characterization of the circumstances in which fiduciary law may award personal or proprietary gain-based relief or additional considerations to be addressed by a court in the imposition of a constructive trust in discretionary circumstances. Rather, in constructing this argument, I have more narrowly focused on providing a principled objective for the imposition of a constructive trust as proprietary gain-based relief for breach of fiduciary duty, in the spirit of the Galambos approach. By grounding this overall discussion towards a conceptual remedial goal of enforcing the undertaking at the heart of the fiduciary relationship, we might slowly help equity to effectively and predictably do what ought to be done. 